\title{
Shaping Narrative Writing Skills Through Creating Picture Books'
}

\author{
Dando forma a las habilidades de escritura narrativa a través \\ de la creación de libros ilustrados
}

\author{
Francisco Antonio Pérez-Gómez and Carolina Vargas Daza ${ }^{2 *}$ \\ Universidad Pedagógica Nacional, Colombia
}

\begin{abstract}
This research sets out to unveil the potential enrichment of initial narrative writing processes in a group of EFL 5th graders through the implementation of picture books as useful tools which can be used to shape the natural ability of telling an event or a sequence of events systematically of EFL students at this level. In this qualitative approach study, writing was regarded as a formal description of structured data which is outlined in the mind, and which has different cognitive stages and works with preestablished categories, as proposed by Flower and Hayes (2008); furthermore, the learning was contemplated from a genre-based approach in which recognizing the needs and proficiencies of the students was the major concern, and this was fueled and supported by the use of familiar routines and cyclical activities in social contexts during the writing process. After following up and analyzing the whole process 5 graders went through in terms of creating a narrative story embodied in the form and principles of a picture book, it was determined that thanks to the use of illustrations, and words students were able to tell simple but meaningful and creative stories about characters (mostly creatures) they used as the protagonists in their picture books. Equally, it was found that the habitual written practices they were exposed to, contributed to a significant extent, to the enhancement of basic narrative writing skills as they were able to express their view of reality in a concrete and simple form, place their basic grammar and lexicon to the service of the narrations they were trying to render and most importantly, they displayed a better capacity of telling an event or a sequence of events systematically.
\end{abstract}

Key words: writing process; picture book; narrative writing; genre-based approach.

\footnotetext{
1 Received: May 1st 2018/ Accepted: October 7th 2019

2 fperez@pedagogica.edu.co; carolina.vd87@gmail.com
} 


\section{Resumen}

Esta investigación se propone asistir al enriquecimiento del proceso de escritura narrativa de estudiantes de inglés de $5^{\circ}$ grado, a través de la implementación de libros álbumes como herramientas útiles que pueden emplearse para modelar la habilidad natural que tienen los estudiantes de inglés como lengua extranjera medio para contar un evento o secuencia de eventos sistemáticamente en este nivel. Para alcanzar éste objetivo, fue necesario entender la escritura como una descripción formal de datos estructurados la cual es esbozada en la mente y que tiene diferentes etapas cognitivas y trabaja con categorías preestablecidas, como lo propuso Flower y Hayes (2008); de igual manera, el aprendizaje fue contemplado bajo un enfoque basado en el género literario donde el reconocimiento de las necesidades y habilidades de los estudiantes fue la principal preocupación, lo que fue soportado por medio de rutinas familiares y actividades cíclicas en un contexto social. Después de analizar el proceso total que experimentaron los estudiantes de grado quinto en términos de la creación de una historia narrativa plasmada en la forma y los principios de un libro álbum, se puedo determinar que gracias a las ilustraciones y palabras, los estudiantes pudieron narrar historias simples pero significativas y creativas acerca de personajes (criaturas en su mayoría) que usaron como los personajes principales de sus libro álbum. De igual manera, se encontró que las prácticas habituales de escritura ellos a las que estaban expuestos, contribuyeron de manera importante a moldear sus habilidades narrativas básicas al escribir, en tanto que fueron capaces de expresar su visión de realidad en una forma concreta y simple, colocando su gramática y vocabulario básico al servicio de las narraciones que ellos querían crear y sobre todo, mostraron una mejor capacidad para narrar u evento o secuencia de eventos de manera sistemática por medio de una contextualización, un clímax y un final.

Palabras clave: proceso de escritura; libro álbum; escritura narrativa; enfoque basado en el género literario.

\section{Resumo}

Esta pesquisa se propõe assistir ao enriquecimento do processo de escritura narrativa de estudantes de inglês de $4^{\mathrm{a}}$ série, através da implementação de livros álbuns como ferramentas úteis que possam empregar-se para modelar a habilidade natural que os estudantes de inglês têm como língua estrangeira média para contar um evento ou sequência de eventos sistematicamente neste nível. Para alcançar este objetivo, foi necessário entender a escritura como uma descrição formal de dados estruturados a qual é esboçada na mente e que tem diferentes etapas cognitivas e trabalha com categorias préestabelecidas, como o propôs Flower e Hayes (2008); de igual maneira, a aprendizagem foi contemplada sob um enfoque baseado no gênero literário onde o reconhecimento das necessidades e habilidades dos estudantes foram a principal preocupação, o que foi suportado por meio de rotinas familiares e atividades cíclicas em um contexto social. Depois de analisar o processo total que experimentaram os estudantes de quarta série em termos da criação de uma história narrativa plasmada na forma e os princípios de um libro álbum, pôde-se determinar que graças às ilustrações e palavras, os estudantes puderam narrar histórias simples, mas significativas e criativas sobre as personagens (criaturas na sua maioria) que usaram como as personagens principais do seu libro 
álbum. Da mesma forma, encontrou-se que as práticas habituais de escritura às quais eles estavam expostos, contribuíram de maneira importante a moldar suas habilidades narrativas básicas ao escrever, pelo que foram capazes de expressar sua visão de realidade em uma forma concreta e simples, colocando sua gramática e vocabulário básico ao serviço das narrações que eles queriam criar e principalmente, mostraram uma melhor capacidade para narrar o evento ou sequência de eventos de maneira sistemática por meio de uma contextualização, um clímax e um final.

Palavras chave: processo de escritura; libro álbum; escritura narrativa; enfoque baseado no gênero literário. 


\section{Introduction}

$\mathrm{N}$ owadays, many children from Colombia deal with problems of writing, not only in their native language but also in a foreign language as English. According to the Ministry of Education in Colombia, all students who are in 4th and 5th grade should be able to write in their EFL class about topics of their interest, make simple descriptions and narrations based on a sequence of images, describe general characteristics about people they are acquainted with, link phrases and sentences using connectors, create short stories expressing their own feelings and preferences, use accurate structures and grammatical patterns of language, double-check the spelling of common words, and make up stories (MEN, 2006), yet students of these grades do not fulfill these writing standards; this has been a constant problem because they do not develop this ability in a proper way at school, and as a consequence they carry on low writing performances and difficulties to other grades.

Thanks to the information collected through the different types of data collection techniques (six-month-observational phase field notes, surveys, and diagnostic test), it was possible to highlight that the preferences of fifth graders under study were focused on reading, listening and speaking in English as a foreign language, which is worth remarking. Nevertheless, this trend showed to us as researchers, that they did not display concern or interest in relation to the development of writing skill which is as important as the other three skills because it is essential in order for them to step into the literary world.

This above-mentioned lack of interest was reflected upon the results students obtained on the written diagnostic section they were administered, in which they were expected to look at a simple picture and write what they understood of it. Almost half of the students did not write a single word, over $25 \%$ of them wrote some simple sentences with many spelling mistakes or syntax errors, $16 \%$ described the picture very well but in Spanish and consequently, did not follow the instruction about using English to perform the task and just nearly $9 \%$ of them wrote some sentences that revealed their having fulfilled the task.

As researchers, we were always aware of the fact that this writing issue was not only evident in their EFL class but also in their Spanish class because for them it was particularly daunting to write a good piece of writing or paragraph in their mother tongue. Melgarejo (2010) stresses out this idea explaining that primary school students in our country do not write good texts in Spanish because they do not have solid grammar structures or understanding of its syntax; however, we are also of the opinion that primary school students may feel frustrated when they to face a written task as they are not familiar with the formats or the assignment that have to do, they do not have the experience to set goals or to think about the potential audience and most importantly, they are not used to writing something as derived from a process. 
We were aware as well that asking students to write in a short description or narrative in English about a picture might be hard for them because syntactically the two languages in question (Spanish and English) are very different, and also because they do not have a referent in their mother tongue to start writing in another language. Marble (2012) provides us with pertinent insight on this situation when he says:

Seeing as how reading and writing are skills which are difficult for emergent students to learn, just imagine if a child is not fluent with the English language. Students whose second language is English have a harder time comprehending texts and composing their own written texts" (p. 29).

Despite all the drawbacks and apparently unsatisfactory scenario, we wanted to embrace a change in methodology to engage students into writing simple narratives where they could tell us and their peers about events, sequence of events, familiar routines and cyclical situations without feeling frustrated and held back by their grammar, vocabulary or syntactical errors. In this respect, we agreed with the postulate of Carter et al. (1998) who think that "although some students are not motivated to write, it is apparent that teachers need to change instructional methodologies to increase their students' written language skills" (p. 10).

Since both of us as researchers had previous research and academic experience revolving around the implementation of storytelling techniques and particularly of the use of picture book to develop communicative skills, we decided to conduct this qualitative study to make use of this tool to shape fifth graders narrative skills and to see whether their interest in this important language skill could be improved by means of picture books (Yoga, 2013).

We acknowledge that the use of pictures books for writing has been widely documented in the field of Spanish as mother tongue by some authors in Colombia such as Triana (2017), who used them to improve guided writing in second grade; Camacho (2016), who attempted to improve fourth graders 'writing skills through the creation of a picture book; Parra and Salazar (2015),who looked to find out whether constructing a picture book would contribute to strengthening written production of third graders and Melo (2013), who used picture books as spatially integrated multimodal texts to improve written production in third graders. After reading the outcomes of 152 these important works, we think that the study we are reporting here might be revealing in that it may shed some initial light onto the way primary school students under study could relate through the progressive use of picture books to the written tasks they were assigned (narratives stories), enriching not only their lexical repertoire and grammar structures in English as a foreign language but more importantly using their imagination to describe and tell a narrative about their most immediate reality. 


\section{Theoretical Framework}

\section{Writing as an English Skill}

In this study, in line with Nunan's definition (1991), we regard writing as a very complex language skill which is highly cognitive, and one which entails not only controlling multiple aspects such as contents, format, sentence structure, vocabulary, spelling and letter formation but also structuring and integrating information into cohesive and coherent paragraph and text.

To us, writing should not be overlooked as a skill which is merely product- conducive but process-oriented. Upon the recognition of writing as a skill, it is important to concentrate on the writing process before aiming to obtain a particular product because writing is a mental process that has different cognitive stages as stated by Flower and Hayes (2008), which means that these cognitive processes could be beneficial for tracing strategies used by writers. Therefore, while trying to understand the writing process, it is relevant to define the main elements or sub-stages that constitute such process that is to say planning, retrieving information, re-viewing, among others.

Accordingly, Flower and Hayes (2008) claim that the first step in the cognitive writing process refers to the context as being the topic for developing the text in later attempts; the second property is about the previous knowledge that the person makes use of and the drafting of the text in order to meet the expectations of a hypothetical audience; and the third consists of the conscious process of self-regulation in the act of writing starting with the planning, reviewing, correcting, etc. Thus, for this study we considered consider writing not only as the sequence of stages to create a product, but also the cognitive process involved in the creation of the piece of work (narratives).

We would like to pinpoint the fact that for the target population, writing in English represented a great challenge, as in principle many of them were not well prepared to undertake because of the unfamiliar and complex discourse patterns that English posed. Thus, teacher guidance was necessary to help students to set strategies, plan the structure of the text, and find information to develop the ideas and topics as well as modify and reorganize them when checking the structure and grammar of the text, fulfill the task of telling an event and tell a simple but coherent and meaningful narratives to their peers in written.

\section{Narrative Writing}

According to the Alabama Department of Archives \& History (2009) narrative writing consists in recounting as neatly as possible a series of actions that transpire in a given period of time, to a reader who is expected to grasp 
the happenings and to follow the sequence of events communicated in the storytelling. Therefore, one with the intention of narrating a story must develop the proper skills to present tales and stories, and become aware of the structured description of information that involves procuring a correct writing schema. Moreover, self-expression and creativity are paramount of the narrative process in writing; yet, Schaefer (2001) agrees with the fact of placing the expressiveness of the writer in the forefront, but she also states that teachers must lead students into developing critical skills for them to use the language to convey their ideas and viewpoints. Which is why, she suggests steps for guiding students into communicating their thoughts by using conventions of language to communicate meaning and employing strategies to write coherent stories with strong characters.

In this fashion, there is more to narrative writing than just self-expressions because this process demands practice in a conscious way, where the writer must keep in mind the techniques of "prewriting, drafting, and revising" (Brown, 2009, p. 348), for the technique of prewriting promotes the generation of ideas, and the technique of drafting and revising encourage the writing into free writing and monitoring their own writing process, respectively. Thus, narrative writing is a process that involves the participation of teachers and students, where the students make use of the motivation of expressing themselves through writing as their primary tool, and the teacher provides the necessary knowledge to accomplish the writing endeavor.

As for the underlying pattern that we should take into account when writing narrative stories, Southall (2001, p.p.3-4) claims that we commonly find two types: the one that revolves around a problem or struggle the main character is going through and tries to find its most likely solution (CharacterProblem-Solution Narrative) and the other one where the character tells the story in first person and speaks of an appealing and attention-grabbing experience, providing descriptions and details (Personal Experience Narrative). In this study, fifth graders had the chance to choose the pattern they felt more comfortable with.

\section{Descriptions in Narrations}

Description is a fundamental element in a text even when it includes images as in the case of picture books since this is not only limited to describing the features or physical attributes of a person, animal or object, a description can go beyond. Thanks to this, attitudes, behaviors and internal characteristics of the characters in a story could be found. There is not possible story in which description is not a part of. Agreeing with Murray and Hughes (2008), describing processes have place in all forms of academic documents: in scientific and technical writing, in research reports, in expository papers, 
and formal essays. Certainly, a well-written paper must include descriptions because they allow readers to make rich images of what is intended to be exposed.

Besides, readers are able to make inferences of what is being read based on their life experiences that allow them to create a concrete image and enrich the description in the text. In this sense, Zwaan (1986) concurs with the idea of the "conceptual breakfast" proposed by Grass, given that when a reader pictures in their mind an image of a breakfast scene, but certain reader will picture the image of a table with butter and jam on it because the reader is inferring what was not mentioned in the text). Thus, descriptions in the text give the reader the possibility to ground the narration and shape it into an image that fits the frame of their previous knowledge or even contextualize it in order to make it closer to their reality.

One tool where descriptions are enriched and are abundant is precisely picture books. It is important to clarify that descriptions do not have to be made in a complex way, sometimes a couple of adjectives to refer to sizes or colors will do, whereas in other cases by mentioning a set of nouns, we can get an idea what a place looks like, as it happens when we describe a what we find in a room. We will refer in the following entry to picture books and how they were conceived of in this study.

\section{Pictures Books as a Pedagogical Tool}

Nikolajeva and Scott (2001) affirm that picture books lean on being plot-oriented instead of being character-oriented; but this does not mean that characters in a story are irrelevant or that they do not display a distinctive personality, on the contrary, picture books permit a different type of characterization where the pictures and the words complement each other or even contradict themselves. The authors also say that the visual description in picture books is somewhat problematic given that some human qualities are difficult to display through illustrations such as bravery or intelligence; the opposite happens when it is necessary to reveal the characters' emotions and attitudes toward certain situations, which means that physical description depends to a large degree, on the illustrator's ability, who can, with great precision, convey information about appearance that would take many words to communicate in much reading time. Conversely, physiological descriptions that can be indicated in pictures need the accuracy of words to depict complex emotion and motivation.

Additionally, these authors point out that in picture books the narration has no space to any interpretation or point of view of the reader, which means that the dialog and illustrations convey straightforward ideas as the central 
feature of this genre. There are two types of illustration: line drawing and full color presentations being both symmetrical. Images also bring the opportunity to communicate two aspects in the story through visual signs: causality and temporality. In terms of time, this has to be inferred as this is shown through the use of some elements that indicate the course of time, for example, clocks on the walls or calendars, sunsets and sunrises. Nevertheless, the dialogs help to complete the information relating to over time creating a connection between the images and relevant moments in the text. And causality is shown through images and text when it is well intertwined. These insight became valid and useful in our study as students were encouraged to always keep a narrative sequence or plot while talking about characters and they were reminded to include images that contributed to making time, cause, space, attitude, etic more understandable.

\section{Methodology}

\section{Type of research}

The present study is based on the principles of action research stated by Burns (2010), which suggest a self-reflective, critical and systematic approach to exploring the teaching context, so the researcher can identify a teaching problem and work on an efficient and effective solution. As written by her, there are four steps to take when conducting a research work to pinpoint teaching problems in a classroom: planning, to "identify a problem or issue and develop a plan of action in order to bring about improvements in a specific area of the research context" (p. 8); to achieve this, we administered a diagnostic test and a survey to the previous head teacher, action, which "involves some deliberate interventions into your teaching situation that you put into action over an agreed period of time" (p. 8); we decided to implement the first sections using picture books to see students' reactions and writing sensitization process, observation, when "observing systematically the effects of the action and documenting the context, action and opinions of those involved" (p. 8); we carried out a rigorous observation process that lasted half a year and then we understood that observation had to to be done throughout all phases of the project, and reflection, to "reflect on, evaluate and describe the effects of the action in order to make sense of what has happened and to understand the issue

156 (...) explored more clearly" (p. 8). We reflected constantly and non-stoppedly on the effects that the use of picture books might have on student's narrative skills and on their contribution to describing meaningful situations. 


\section{Data collection instruments and procedures}

The present research started with the observation of $5^{\text {th }}$ grade students at a primary public school in Bogotá in order to identify the struggles they had when using English as a foreign language in terms of communication and simple expression of events or situations that happened in their most immediate surroundings. Through the use of several instruments (survey to head teacher, comprehensive diagnostic test and field notes), it was possible to pinpoint the most common and persistent difficulties that these students exhibited, being those difficulties particularly related to writing: fifth graders did not possess the necessary basic written skills to tell or narrate a simple story represented in a picture. They could write ideas about the picture but in their mother tongue, that is to say Spanish. With this concern in mind, we set the following goal as the one to reach in our study: to make fifth graders write simple narrative stories related to their context by using picture books as tools and despite their not so proficient grammar, lexicon and writing skills.

To carry out data analysis, it was necessary to work on the microanalysis suggested by (Strauss \& Corbin, 1990; Patton, 2002) that implies to read line by line all the raw data that were collected during the implementation of the research, to make an in- interpretation; after reading this, the researchers established a way to join the information of the data into categories. It was important to pay attention to the words the students tended to say. The next step was to find recurrent regularities through the data (Patton, 2002) in order to clarify the categories taken from them by the researcher. Then, the researchers were able to choose pertinent categories and sub-categories according to the information given by the data (Freeman, 1998). In regards to the surveys, they were analyzed with a similar system. The first step was to count the answers of the yes or no questions to set the patterns and the variations. Following, the open-end questions were checked one by one paying specific attention to the similar answers and the details of the reasons given. To make the information valid, the researchers took into account the triangulation process, which implied having at least three data instruments such as survey, document collection, and field notes. On the one hand, a comparison between instruments was made to get onto the categories and subcategories that were chosen, and on the other hand,the information was made real by taking samples of the instruments, giving validity to those categories and subcategories (Freeman, 1998, p. 102).

Finally, the learning issue was singled out; it was necessary to review the theoretical background to establish a suitable course of action to help students overcome these writing needs. Therefore, according to the learning style of students the approach that successfully worked for them was the genre-based and so, the lesson planning followed the next structure: building the context, modeling the text, joint construction of the text and independent construction of the text. 


\section{Participants}

Regarding participants, the target population of this study was made up of 21 males and 11 females with an average age ranging from 9 to 10 years old. Concerning the cognitive aspect of students, the students seemed to have some difficulties in output skills because what they knew in terms of language was based on the process of repetition. Based on the diagnostic test authored by the teacher-researchers, and adapted from MYELT which is a platform created by the National Geographic, fifth graders were ranked in A1 level in most of the skills as established by the Common European Framework (2015).).

In relation to speaking, the diagnostic test was divided into two groups, spoken interaction and spoken production; for the first group, the students could interact in a simple way provided the other person was prepared to repeat or rephrase things at a slower rate of speech and help to formulate what [tried] to say, they could ask and answer simple questions in areas of immediate need or on very familiar topics. However, for the second, the students were not able to use simple phrases and sentences where they live and people they know, nor they were able to "write a short, simple postcard and fill in forms with personal details" for whatever reason it was.

When the students had to work on the writing part which consisted in looking at a picture and writing what they understood of it, $46,8 \%$ of the students did not write a single word, $28,1 \%$ wrote some sentences with many spelling mistakes or syntax errors, $16,2 \%$ of the students wrote sentences in Spanish that described the picture but did not follow the instruction and just $8,9 \%$ of the students wrote some sentences that followed the task. Regarding the grammar and vocabulary sections that are considered a part of writing production, the results were very much alike to those of the writing part.

In the listening section, the students had to listen to a recording about contractions of pronouns and verb to be vs possessive pronouns and select the correct words to complete five sentences, $25 \%$ of the students did not mark any answer, and $37,5 \%$ of them made up to 2 mistakes, and $37,5 \%$ got all of the answer right. In the reading section, all of the students showed a good understanding of the article which is why they selected the correct answers of the questions relating to the text, the questions were multiple choice-oneanswers.

All in all, it was possible to ascertain that the skill that needed to be addressed the most was the writing skill because the students' performance was below the average, portraying a $74,9 \%$ of deficiency, and the lack of vocabulary and grammar structures could make relevant the choice of enhancing or expediting their writing production in very basic forms, such as writing postcards, filling in registrations or filling out forms. 


\section{Findings}

The collected data in this research was analyzed following the principles of the grounded theory proposed by Freeman (1998), the idea of using this analysis approach was to find out the correlation between all the data we collected and the usage of picture books as a strategy to approximate students to writing in a foreign language. Hence, we assert that our research might be useful to gain insights in aspects such as language relationships, goal-based learning strategies, comprehensible meaning targeting and personal expression in language learning because by creating personal pieces of work in the form of picture books, students account for the learning of English as a foreign language and at the same time, they can integrate the content knowledge provided in the classroom with the communicative endeavor of getting messages across in a real context, based on meaningful personal experiences .

Like so, the categories that account for each one of the aforementioned aspects were clustered around the question "How might 5th grade EFL students in IED Domingo Faustino Sarmiento narrative writing skills be shaped through creating picture books?". The categories that emerged were labeled as performing skills to accomplish goals, input effectiveness and self-expression. Now, we proceed to elaborate in depth the findings of our research.

\section{Performing Skills to Accomplish Goals}

This category is related to the teaching and learning structure named goal-based scenarios (GBSs) developed by Schank, Berman and Macpherson (2009),which advocates for a learning-by-doing strategy through which students engage in practices that focus on a specific skill, where the content knowledge is the means for them to accomplish what they have set out. In this GBS simulation, the teacher only assists students in making the content knowledge relevant for them to achieve their goals and also, s/he provides feedback so that the students remember and internalize what they were taught or assisted on. In relation to this, the goal that students were supposed to achieve was to create simple but meaningful written narratives embodied in a picture book; thus, this category is elucidated in the production of a piece of work and in turn, the creating process and the final product show the disposition of students to complete tasks for reasons such as sense of fulfillment or teacher encouragement. The following are the exhibits for supporting the current category through triangulating the data obtained: 


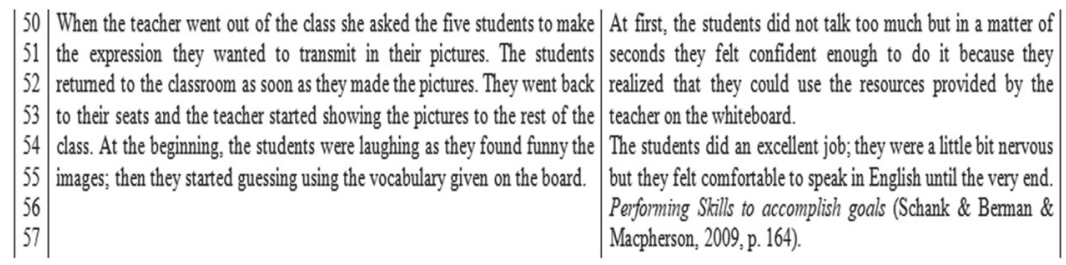

Figure 5. Sample Two. Field Note, March 2017.

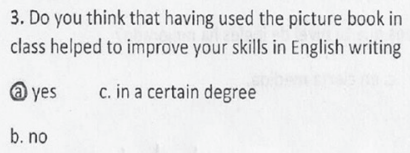

Figure 6. Survey Number Two, October 2017.

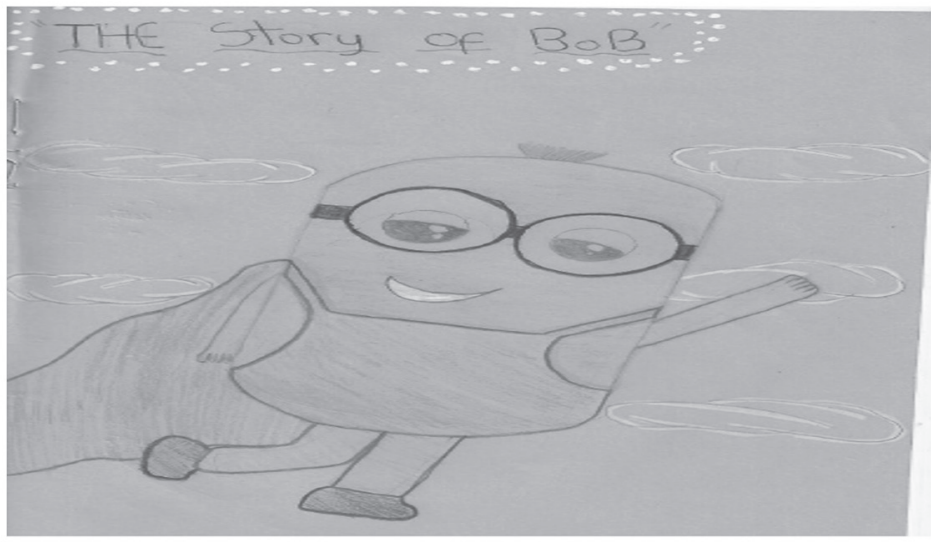

Figure 7. Artifact Number Two, May 2017.

In the three samples shown above, the goal that students were supposed to achieve was the creation and authoring of a personal picture book by performing a task focusing on writing skills; thus, this category of performing skills to accomplish goals is elucidated in the production of a piece of work and in turn, the survey throws light on using the picture book as a tool for improving the writing skills of students as in the title of the cover page of the picture 
book entitled "the Story of Bob", where the author exhibits understanding of the basic use of the definite article which implies articulation with the entity later mentioned in the same sentence (in this case, Bob), or even in the use of the preposition that expresses belonging to the entity as something he has or possesses, rather than using the possessive noun (Bob's story), making the title sound elaborate and appropriate for the English level students are placed; at the same time, the field note shows the disposition of students to complete tasks for reasons such as sense of fulfillment or teacher encouragement, for the students realization of process as a means of progress.

There was a sub-category that emerged from the previous category and we named it Spoken and Written Modes of Meaning. Such subcategory tended to unveil and display different kinds of complexity; both spoken and written modes were progressively more complex in their own way. On the one hand, written language tended to be lexically dense, but grammatically simple; spoken language tends to be grammatically intricate, but lexically sparse" (p. 61) which was mentioned by Halliday (2002); in this regard, the degree of complexity of these types of operations of communicating (spoken) or storing (written) information became higher when students tried to mix the two modes of meaning when facing a specific task that implied selecting one communicative skill or the other; consequently, for this research the students were guided mostly to identify lexical mistakes rather than correcting grammar inadequacies through a process of putting into practice the content knowledge provided by the teacher in a self-led way that was undertaken in the independent construction of the text stage of the lesson planning because "the lexical density [in the written mode of meaning] is the proportion of lexical items (content words) to the total discourse" (Halliday, 2002, p. 56), reason why one of the most recurrent issues while creating the picture books in our attempt to shape narrative writing skills was that students struggled to broaden their lexicon.

Bearing the aforementioned issue in mind, we decided every lesson planning should include a modeling and independent stage, where the teacher and the students had specific duties to be carried out, but they could partake in each stage as subjects of exemplification or active subjects of the learning process (students) and subject of explanation and source of knowledge (teacher) instead of passive subject who merely offered guidance and advice.

Now, with the intention of supporting what was stated above, here are the corresponding samples for the triangulation of the information: 
26 The teacher hung some sentences expressing daily routine on the right side This activity seemed to be really challenging for the students

27 of the board and on the left some pictures showing some people and animals perhaps they were confused as they could not find any relation

28 doing different activities. The teacher called one person at random and asked between the written sentences and the images. Some students

$29 \mathrm{him}$ to select one number from 1 to 32 , the teachers checked the roster and could accomplish their sentences but only when the teacher

\begin{tabular}{|l|l|l|l}
\hline 30 & checked the name that corresponded to the number selected, and that student & read the sentences aloud. This shows that students still have a
\end{tabular}

31 had to go to the board and select one sentence and paste it with the picture degree of conflict making the relation between written English

32 that matched.

\begin{tabular}{|l|l|}
\hline Modeling the text & All students \\
\hline Activity 1: The teacher is going to explain the communicative function as well as the & 30 \\
structure of adjectives to describe feelings and emotions on the board. First, the teacher & mins \\
explains the purpose of using these types of adjectives to narrate and to complement & \\
information in images; second, the teacher is going to explain the simple present with \\
verb to be to use adjectives and the teacher can ask for the help of students to contribute \\
in the exemplification of the topic. \\
Activity 2: The teacher is going to show flashcards with some faces on them and \\
students are going to guess how those people are feeling. After they give the right \\
answer they have to mimic the face from the picture to show the same emotion. \\
Alternative activity: the teacher is going to pick 5 students to make pictures of their \\
faces showing different feelings. For this activity a tablet is going to be used to show the \\
rest of the class. A poster with the vocabulary needed is going to be hung on the \\
whiteboard.
\end{tabular}

\begin{tabular}{|c|c|c|}
\hline Independent construction of the text & & \\
\hline $\begin{array}{l}\text { The students are going to create the four draft of their own picture book, in this occasion } \\
\text { the teachor is going to hand out students pieces of paper with two panels in which } \\
\text { students have to draw on the right pancl the antagonist of their stories. On the left side } \\
\text { they have to mention the physical characteristics of this character. Students can check } \\
\text { their previous drafts as there are many different ideas to be used for this activity. }\end{array}$ & All students & $\begin{array}{l}25 \\
\text { Mins. }\end{array}$ \\
\hline
\end{tabular}

Figure 8. Sample Three. Field Note, April 2017.
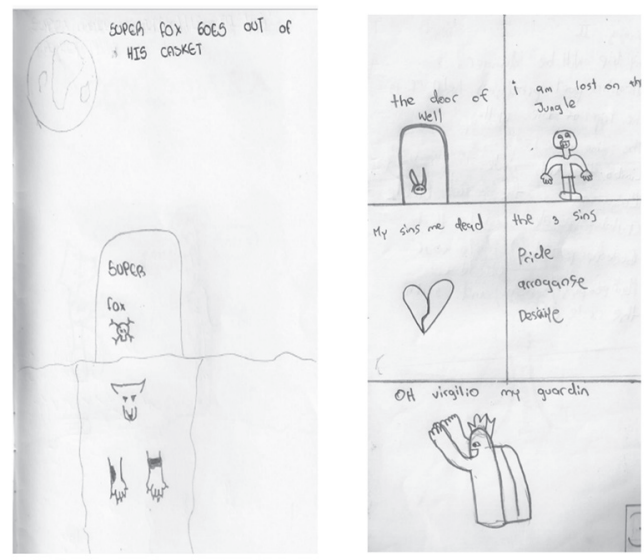

Figure 9. Artifact Number Three, June 2017. 


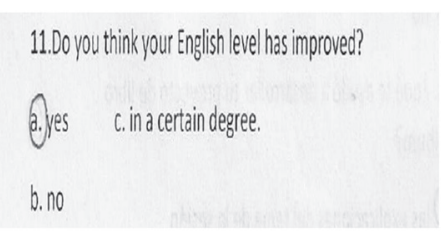

11.Do you think your English level has improved?

(2)yes c. in a certain degree.

b. no

Figure 10. Survey Number Two, October 2017.

The field note referenced above revealed that students had some struggles relating the spoken English with written English. As it was exposed in this sub-category, this happened because of the difficulty that each skill entailed. Nevertheless, students were gradually integrating the vocabulary taught in the classroom by the teacher-researcher depending on what they needed to express in their productions as it is evidenced in the sentence "Super fox goes out of his casket" where the student chooses the word "casket" instead of "coffin" because the first was more appealing to him, even though the two would have served the same purpose. Like so, the lesson planning fragments illustrate the classrooms routines that helped students develop a writing habit perceived as the artistic conduit for students to express their ideas in a simple way, given that language learning process was centered on the making of a written piece of work. Additionally, $75 \%$ of students considered that their English level improved with every lesson and activity carried out in the classroom which was asked in 10th question of the survey. The result of the surveys is highly subjective indeed, the number of well-designed picture books created along the implementation of this research project are a proof that students had become more competent in the written aspect of the language considering that, they had had to face many learning obstacles due to the limited exposition to the language.

\section{Self-Expression}

According to Tudor (2000) self-expression is part of the central purposes in language. Likewise, personal expression is a vital element of language use and 'the 'opening up' of a course to at least some degree of self-expression can help learners find a sense of personal meaningfulness in their language study" (p. 61). In this sense, the lack of any extent of self-expression can lead students to perceive the classroom as something alien to their realities and lives. Therefore, students will not have the possibility to engage in significant learning processes. That is why:

[Self-expression] is one of the main functions of language, and it would therefore be rather strange if it had not found a place to in mainstream 
language teaching. Indeed, the way in which this aspect of language is dealt with a course can play a significant role in the classroom dynamics. (p. 68)

In this fashion, the next set of artifacts and excerpts evidence the category of self-expression in students' written pieces:

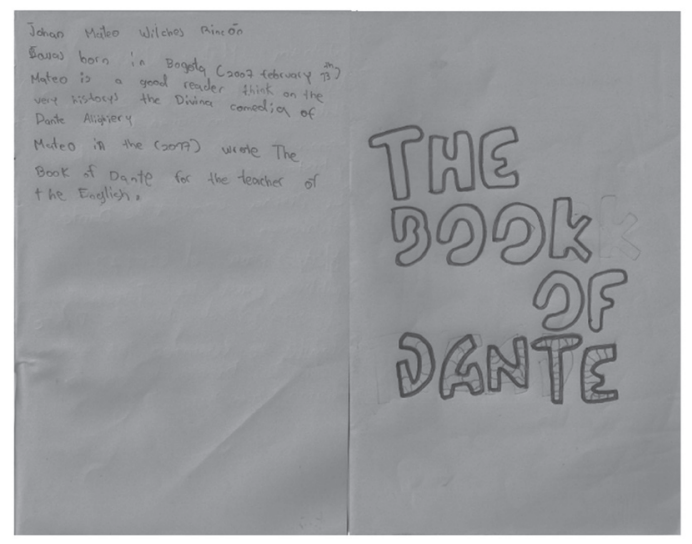

Figure 14. Artifact Number Five, September 2017.

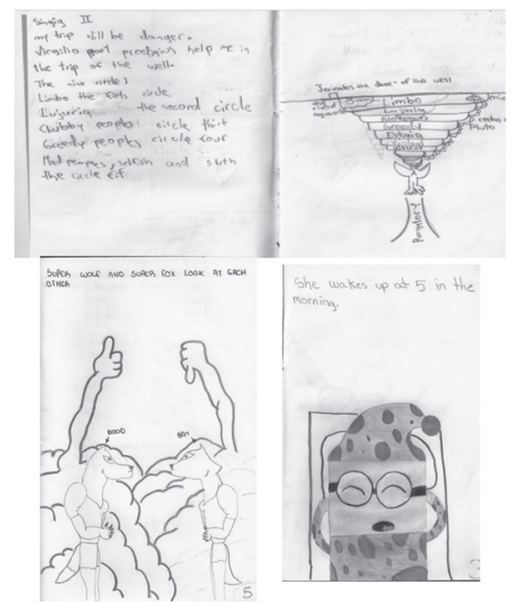

Figure 15. Artifact Number Six, September 2017. 


\author{
8. What is the origin of your idea for the picture book? \\ a. from television \\ b. from a book \\ a. from my own imagination. \\ 9. Does the protagonist of your story represents you in \\ any way? \\ 8. yes c. in some aspects. \\ b. no
}

Figure 16. Survey Number Two, October 2017.

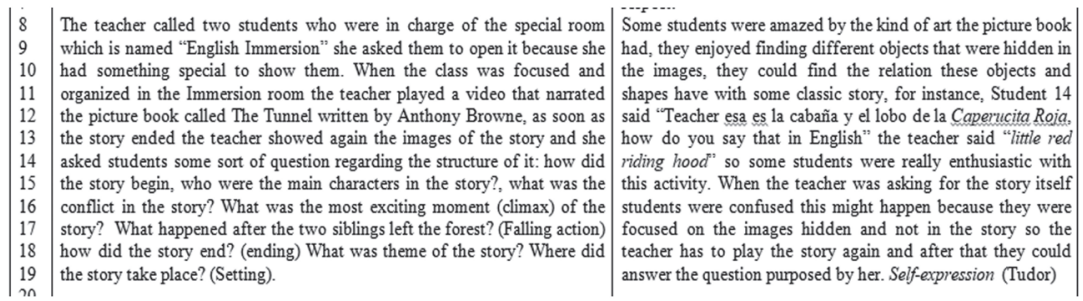

Figure 17. Survey Number Two, October 2017

As such, the texts written by the student are proof of the impact that The Divine Comedy by Dante Alighieri had on his life because it is not by chance that the student decided to shape his picture book according to this literary master piece and use its contents as the source of his inspiration and above all, to regard himself as a "good reader". Therefore, in the process of creating a narrative document each student felt the need to materialize their inner thoughts and realize the urges that drove them, so the proposal of this research was a suitable conduit for them to express what at first, they only thought could be done in Spanish or by people with literary expertise. Thus, not only "The Book of Dante" is proof of the significance of this research project to students, but every single piece of work has become a concrete personal creation that includes information related to their experiences, artistic desires and hopes for the future. In this way, students have had the opportunity to narrate a fictional story that places them as the main character of their stories for each one of 
them want to be the superhero that saves the day and all the people admire, thanks to their prowess and morally-correct ways, that is why, it is possible to know that the writer of the story "The Story of Bob" is a girl because of the use of the personal pronoun "she" that was used to refer to Bob.

\section{Conclusions}

In the first place, it is worth remarking that throughout this research there was a lingering hope that narrative writing skills could be shaped by creating picture books, particularly of the fictional type, in the creation of such books illustrations and words were equally important given that both helped students to narrate their stories. In general terms, students used illustrations as well as words to situate narratively speaking, the creatures they chose as the protagonists of their picture books. The execution of this literary genre aimed to enhance writing skills through habitual practices guided by the teacherresearcher.

In line with what was stated above, it is possible to ascertain that having implemented this type of literary devices helped students relate to the writing task and enrich their repertoire and grammar structures in English as a foreign language, as it happened in the use of words such as "casket" or "chamber"; as can be evidenced in terms of subject-verb agreement in the utterance "super wolf and super fox look at each other" or in "she wakes up at 5 in the morning".

As for our attempt to mold students' capacity of telling an event or a sequence of events systematically, it can be said that there was an important progress in this respect as it can be seen in the story "The Super Wolf and Fox", where the author opted to begin by contextualizing the wealthy origin of Super Wolf and the poor provenance of Super Fox, decided to climax with the clash of the hero with his antagonist and chose to conclude with the coming to terms between the two characters. Broadly talking, the final written outcomes were satisfactory as students evidenced a gradual upgrade in their writing performance, which came to be little by little as the they got used to the classroom tasks that focused on building vocabulary, and the logical and chronological sequence of narrating a story, and finally, the internalization of abstract notions such as first, second and third persons in singular and plural forms.

According to the main objective of this research which was to analyze the students' EFL writing skills when narrating simple stories through the use of picture books, the writing process was the central axis of this research, so the expected impact of implementing picture books was accomplished as this had a positive and meaningful effect on students' writing process in a foreign language. This contributed to the understanding of written language in order 
to give students the opportunity to express their view of reality in a concrete form.

As such, in order to characterize students' understanding of the stories told in picture books this research worked on the development of specific stages laid out in the lesson planning that aimed to allow students to employ the vocabulary and grammar structures exposed in the reading aloud of the pictures books, and at the end of every session they had to include the content knowledge into their own pieces of work, so the learning of the topics was made clear in a written form. In this way, the outcome of this specific objective was successfully achieved for the input provided in the lessons was evidenced in written materials that each student created to make the output tangible.

Similarly, to determine the influence of this (picture books) new genre of literature in fostering meaningful writing processes the researchers measured the suitability of the tool selected for this research, according to the degree of motivation and participation in class displayed by the students during the lessons which was positively accepted, as it became the means for the children to materialize their ideas and to express their individuality through graphics and words meant to communicate.

Finally, the researchers made use of different strategies to examine writing processes based on the creation of picture books, such as creating a correction-code based on the emoji system used to express ideas or emotions because students were more likely to understand the mistake and correct it through their own means; another strategy was the use of drafts for the students to polish up the final version of their own picture books, so they had the possibility to modify the stories narrated as many times as they needed, or until they felt satisfied with the development of the pieces of writing.

\section{Pedagogical Implications}

The pedagogical intervention of this research aimed to helping students confront writing as a means to communicate thoughts and ideas, besides assisting in the fostering of writing skills in a foreign language. In this manner, this research was expected to have a positive and meaningful impact on teaching and learning of English as a foreign language. This implies understanding and assimilating writing processes in order to communicate and to transmit ideas in a concrete form, so the most important aspect of written language is the capacity to surmount the passing of time and to turn the abstract of fancies into the concrete of realia. Therefore, teachers should focus on what the students want to say, so the process becomes the central axis of teaching. Thus, teachers should support and understand students' needs and interests through engaging in and accompanying their own learning process. 


\section{References}

Aguirre, A. J. (1988). code-switching and intutive knowledge in the bilingual classroom. (I. D.-M. Orntein-Galicia, Ed.) Chicago Speech in the Bilingual.

Alabama Department of Archive \& History. (n.d.). Definition of Narrative Writing. Retrieved from http:/www.archives.alabama.gov/teacher/ TEFABH_Narrative_Writing_Exercise.pdf

Brown, H. D. (2001). Teaching by principles: an interactive approach to language pedagogy ( $2^{\text {nd }}$ ed.). New York, NY: Pearson Education

Burns, A. (2010). Doing action research in English language teaching: a guide for practitioners (1st ed.). New York, NY: Routledge

Camacho, K. (2016). The picture book as a tool to enhance writing skills (undergraduate thesis). Universidad Pedagógica Nacional, Bogotá, Colombia

Carter, P. et al. (1998). Improving student writing skills using wordless picture books (master thesis). Saint Xavier University, Chicago, USA. Retrieved from: https://archive.org/stream/ERIC_ED423525\#page/n1/mode/2up

Chu, C. (2011). Picture book reading in a new arrival context: a multimodal perspective on teaching reading (Ph.D. thesis). University of Adelaide, School of Humanities, Adelaide, Australia.

Driggs, C. \& Sipe, L. (2007). A Unique Visual and Literary Art Form: Recent Research on Picturebooks. Language Arts, 83(3), 273-280. Retrieved from: http://repository.upenn.edu/gse_pubs/32

Flower, L. \& Hayes, J. R. (2008). A Cognitive Process Theory of Writing. College Composition and Communication, 32 (4), (Dec., 1981), 365-387. Retrieved from: http://www.jstor.org/stable/356600

Freeman, D. (1998). Doing Teacher-Research: from inquiry to understanding. Canada, CND: Heinle \& Heinle Publishers.

Gerard, E. (2008). Picturebooks as visual literacy: the influence of illustrations on second-graders' comprehension of narrative text. Retrieved from: http:// drum.lib.umd.edu/handle/1903/8999

Grundvig (2012). Can picture books in the English classroom lead to increased reading comprehension? Reading skills: Strong and Weak readers' use of Reading strategies with emphasis on Decoding \& Visualization. Høgskolen i Østfold, Østfold Norway.

Hughes, C.E. et al. (2000). Code Switching Among Bilingual and Limited English Proficient Students: Possible Indicators of Giftedness. Journal for the Education of the Gifted. 30 (1), 2006, pp. 7-28. Retrieved from: http:// files.eric.ed.gov/fulltext/EJ750758.pdf 
Krashen, S.D. (2009). Principles and practice in second language acquisition. Internet Edition.

Marble, S. (2012). How Do Wordless Picture Books Help Develop Writing For All Students? Fisher Digital Publications. Retrieved from: http://fisherpub. sjfc.edu/cgi/viewcontent.cgi? article $=1229 \&$ context $=$ education_ETD_ masters

Melgarejo, D. (2010). Assessing Children's Perceptions of Writing in EFL based on the process approach, 12, 70-84. Retrieve from: http://revistas. udistrital.edu.co/ojs/index.php/calj/article/view/92/140

Melo, A. (2014). Procesos de comprensión y producción de textos multimodales a través del libro álbum. Revista Folios de Humanidades y Pedagogía, 37 -56 .

Murray, N. \& G. Hughes. (2008) writing up your university assignments and research projects: a practical book. Maidenhead, England; New York: Open University press.

Nikolajeva, M. \& Scott, C. (2006). How picturebooks work. New York: Routledge.

Nunan, D. (1991). Language teaching methodology: A textbook for teachers. Edinburgh, Harlow, England: Longman.

Pantaleo, S. (2009). The influence of postmodern picturebooks on three boys' narrative competence. Australian Journal of Language and Literacy, 32(30), 191-210. Retrieved from: http://jgarich.pbworks.com/w/file/ fetch/46044586/The $\% 20$ Influence $\% 20$ of $\% 20$ Postmodern $\% 20$ Picture $\% 20$ Books.pdf

Parra, D. \& Salazar, A. (2015). El libro álbum como estrategia didáctica para el fortalecimiento de la producción escrita en la lengua castellana (undergraduate thesis). Universidad Libre, Bogotá, Colombia

Patton, M. (2002). Qualitative research and evaluations methods (3 ${ }^{\text {rd }}$ ed.). Thousand Oaks, CA. Retrieved from: https://bibliotecadecienciassociales. files.wordpress.com/2014/02/qualitative-research-evaluation-methods-bymichael-patton.pdf

Shaefer, L. M. (2001). Teaching Narrative Writing: the tools that work for every student. New York, NY: Scholastic Professional Books.

Schank R.C. \& Berman T.R. \& Macpherson K.A. (2009). Learning by doing. In C.M. Reigeluth (Ed. 2), Instructional-Design Theories and Models: a new paradigm of international theory (pp. 161-186). New York, NY: Routledge. 
Strauss, A., \& Corbin, J. (1998). Basics of qualitative research: Techniques and procedures for developing grounded theory ( $2^{\text {nd }}$ ed.). Thousand Oaks, CA: Sage.

Southall,M. (2011). Narrative Writing. Toronto: The Curriculum Services Canada Foundation.

Triana, P. (2017). Children Picture Books to implement a first approach to writing (Undergraduate thesis). Universidad Pedagógica Nacional,Bogotá,Colombia.

Tudor, I. (2000). The Dynamics of the Language Classroom. Cambridge University Press.

Yoga, A. S. (2013). Improving the eighth grade students' writing skills through picture-cued activities at smp $n 1$ wonosari in the academic year of 2012/2013. Retrieved from: http://eprints.uny.ac.id/22543/1/Adwidya $\% 20$ Susila\%20Yoga\%2008202244041.pdf

Zwaan, R. A. (1993). Aspects of literary comprehension: a cognitive approach. Amsterdam, AN: John Benjamins Publishing Co. 


\section{Authors}

*Francisco Antonio Pérez-Gómez is a full-time professor and researcher at Universidad Pedagógica Nacional. Holds a Master's degree in TEFL and another one in Teaching Spanish as a Foreign Language from UNINI University, Puerto Rico. His research interests include Teaching English as a Foreign language, teaching practicum, interculturality and teachers professional development, amongst others.

ORCID: https://orcid.org/0000-0002-0514-1609

Carolina Vargas Daza has worked for 5 years teaching English in Bogota. During her 4th year of university, she worked for one year in an elementary school setting teaching English as part of the research project in question. She is currently studying an M.A TESOL in Northern Ireland for which she is already preparing her next research project.

ORCID: https://orcid.org/0000-0002-5368-8799 